\section{British Commonwealth Scientific Conference}

A Conference was opened by the Right Hon. Walter Elliot, M.P., Minister for Agriculture, and attended by representatives of the Governments of all portions of the British Commonwealth, on the morning of Monday, September 21, in London. Its chief function is to examine the work and future of a number of scientific organizations established on a co-operative basis to perform a common service in various branches of agricultural scientific research. As a result of the Imperial Agricultural Research Conference of 1927, the several Governments of the Empire agreed to establish bureaux or centres of information in eight branches of agricultural science, financed by contributions from all parts and controlled by a council representative of all parts of the Empire. To these, the supervision of two older institutes was added in 1933 on the recommendation of the Imperial Committee on Imperial Economic Consultation and Co-operation. In addition, the Conference is considering the future of certain research schemes to which several parts of the Empire now contribute, and also further methods of the interchange of information and closer collaboration in scientific work.

After the opening meeting on Monday, the Conference inspected the bureaux and centres of information which deal with mycology, soil science, animal health, animal nutrition and genetics, plant genetics (non-herbage and herbage), fruit production, and agricultural parasitology. The Conference re-assembles in London on October 2. The Executive Council of the Imperial Agricultural Bureaux, of which Sir Charles Howell Thomas is the chairman, is responsible to all Governments of the Empire equally for the administration of these common services, and in conformity with the resolution of the Imperial Conference of 1926 is constituted on a basis of equality of representation. It was decided by the Governments in 1933 that where such common organizations are formed, their activities should be subject to detailed examination at periodical conferences. This Conference serves that purpose.

\section{Species in Foraminifera}

THe veteran palæontologist, Frederick Chapman, who has retired from the National Museum at Melbourne and is now consulting palæontologist to the Commonwealth of Australia, has contributed to the Melbourne Age (under the initials F.C. and under date February 8, 1936) a column headed "The Species Nightmare: an Absorbing Scientific Problem". One of the oldest living authorities on the Foraminifera, trained under H. B. Brady, W. Kitchen Parker and W. Rupert Jones, whose assistant he was until his appointment to Melbourne, he deals with this difficult question, quoting Mr. Heron-Allen's communications to Nature of July 14, 1934 and November 16, 1935. Frederick Chapman deals with it in connexion with other branches of palæontology, and deplores what Heron-Allen termed "the commercialisation of Protozoology", and his article, which is worth the serious attention of all systematists, but is too long to quote adequately, should receive careful attention. Mr. Heron-Allen is consulted by many of the rising school of petroleum geologists at the Natural History Museum, and, regard being had to the deplorable fact that their lists of species are now regarded as a 'trade secret' not to be divulged for the information of rival petroleum merchants, his advice to these young men is to adhere to the genera established by the great nineteenth century school, both in England and on the Continent of Europe, and to distinguish their species, for their own reference and guidance, only by numbers, or by letters of the alphabet, ignoring the thousands of names given to minor varieties by the American School. By this means they can save themselves an immense amount of labour and brain-fag, and their tabulated results are quite as useful as they would be if they were overloaded by a vast nomenclature which it is impossible -and unnecessary--for the human brain to retain.

\section{Invention and the Modern State}

THE externals of modern civilization are the products of invention, and a scientific analysis of invention, what it is, what causes it and whither it is leading us, is long overdue in England. In such an analysis the statistical method must predominate and the easy generalization will have no place. It may require research of a difficult and unusual kind, but unless we know, for example, accurately and in detail, the origins, the training and the methods of successful present-day inventors, we do not know the sources of the real progress-making inventions of to-day, and while we are ignorant of that vital fact the recital of a short list of so-called workingman inventors of the eighteenth century is not merely valueless but also misleading. Mr. C. W. Marshall has just concluded in the Inventor a series of articles on "The Science of Invention". In them he attempts to interest and guide inventors of various degrees of proficiency, but, although the trend of recent patent applications can be learned from them, the articles are entirely devoid of statistics. As a consequence of this and of the very diverse standards of the inventors to whom the articles are addressed, their total effect is confusion. At one place advice is being given as to the "psychological factor" ; for example, "a camera idea, may be submitted to manufacturers in the autumn so as to be ready for the spring sales". Shortly after this we learn-or do we ? - that the "price of inventions used to vary from $£ 1,000$ for 'gadgets' to half a million for inventions such as refrigeration and automatic photo machines". Again, "There is a ready market for inventions which cheapen production of exclusive products. By introducing mass-production machines and an entirely re-designed, simplified product the early Fords were able to tap the potentially great motor-buying publie".

No one, it would appear, would care to challenge Mr. Marshall's contention that "so keen is the competition, so deep the technical advance now, that the 
principle of hit or miss, except perhaps in the gadget class of invention, is not applicable, and the complete inventor is a development of the scientific researcher". But to such a man, the suggestion that he would find it worth while studying Max Planck, Einstein and Eddington would come rather late, while that suggestion, even if accepted, would have no utility to the 'gadget' producer. The high hopes raised by the receipt of a treatise with the title "The Science of Invention" remain unfulfilled by Mr. Marshall's series. An authoritative examination of the position of invention in the modern State is still needed. In such an examination the commercial aspect may well prove to be insignificant, although research by one man or one set of workers may have to be restricted to the material inventions, leaving such things as modern systems of government, the most striking development of man's inventive faculty, to the historian or the alienist. From a calm investigation of the uses of material advances it may be found that they follow social changes and are called forth by them : but research is necessary to discover the vital facts of modern invention and, in Great Britain at any rate, there is little evidence that such research is being carried out. Is it fantastic to believe that if it is ever adequately made, we shall have general consent to the idea of complete control by the State of the inventive faculties of its members ?

\section{Viability of Plant Structures}

THE question of the length of the period of viability in seeds and other plant organisms is constantly cropping up, and, although a great deal has been written about it, there is still much to be discovered with regard to the actual length of time seeds and spores can remain viable. Reference was made to this problem in NATURE of May 2, 1931, p. 675, and an article on the subject was published in the Kew Bulletin of 1933,p. 257. In that article, all the cases of longevity that have been definitely authenticated were brought together. Possibly the oldest case is that of Nelumbo (the Japanese lotus) recorded by Ohga in the Botanical Magazine of Tokyo, 1923. Seeds of Nelumbo nucifera were found in a peat bed. buried under $2 \mathrm{ft}$. of loess in Southern Manchuria. The seeds all germinated and it is estimated that they were at least 120 years old and may have been as much as 400 years. It is well known, of course, that poppy seeds and charlock can retain their viability for very long periods, but for how long one cannot say definitely. According to an announcement in The Times of August 19, M. P. N. Kaptereff has succeeded in reviving plant organisms which have lain in the earth for thousands of years. It appears from this account that it is only spores which have shown signs of life, and it seems quite possible that spores of some of the lowly algæ could have survived in a frozen condition for a very long time. From the account it appears that blue-green algæ may be some of the plants which have developed - possibly some of the unicellular green algæ also. As to the grass-like plants which are mentioned, they might well have retained their general appearance in a frozen condition for a very long time, as the ice would preserve the form perfectly well. One would not expect them to have any life in them and this does not appear to have been the case.

\section{Native View of Baganda Institutions}

AN account by an African of his own institutions must normally, though not invariably, have an exceptional value for the ethnographer. Being as a rule a spontaneous production, it avoids the great danger of the usual method of inquiry, in which there is the risk of biasing the sources of information. Sir Apolo Kagwa, the Katikiro of Uganda, who produced in 1918 an account of Baganda history and institutions in his native language, was exceptionally well qualified for this undertaking. A man of considerable intellectual power, he had been associated with the royal household from his early youth, and when in 1897 the young Daudi Chwa, an infant, one year and six months old, was appointed king on the abdication and flight to German East Africa of his father, Mwanga, Apolo was made regent and prime minister. He thus had a personal and intimate knowledge of the critical times which led up to the intervention of the British forces in Uganda and the institution of a protectorate. His authority on State affairs and ritual is beyond question. One of the most valuable records he has preserved is that of the officers and queens of each ruler from the beginning of the line with the semi-legendary founder Kintu. The Rev. J. Roscoe, when collecting information for his book "The Baganda", derived a great deal of his material from the Katikiro ; and, in fact, Sir Apolo's book, which is an invaluable, and indeed a necessary, supplement to Roscoe, was written to expand and correct what he considered to be open to criticism in the work of the latter. The fact that Sir Apolo wrote in Luganda has proved a drawback; but this has now been remedied in a translation by Ernest B. Kalibala, edited by May Mandelbaum (Edel) (Columbia University Contributions to Anthropology, 22, 199. 4 dollars). For the convenience of students the mere repetitions of Roscoe's information are omitted, but references to "The Baganda" are given here as well as where Roscoe is supplemented or corrected.

\section{Safety in Mines Research}

As in past years, the Fourteenth Annual Report of the Safety in Mines Research Board includes a report of the Health Advisory Committee, which forms in fact Part 4 of the Report, the previous parts being Part 1, General ; Part 2, Instruction; and Part 3, Progress of Safety Researches. The Report, of course, begins with an expression of regret on the death of Dr. J. S. Haldane, who "had been a member of the Board since 1923" ; there is not a miner who will not re-echo the last sentence of the first paragraph in reference to Dr. Haldano- "His death is a severe loss to the whole mining community" ; whilst it also refers to the retirement of Prof. S. M. Dixon, who, as is well known, has rendered much valuable service in connexion with wire ropes used in mining. There is further a number of appendixes to the Report, one of which deals with protective equipment, and it is interesting to note that, generally 